\title{
THEATRE AND REVOLUTION IN CLINICAL LEGAL EDUCATION
}

\author{
JoNel Newman, Fergus Lawrie, Donald Nicolson, \\ and Melissa Swain*
}

Why does a revolutionary theatre method developed in the 1960s and 1970s by Brazilian intellectual and activist Augusto Boal belong in clinical legal education? Use of the transformative Forum Theatre method can greatly enhance legal education. Boal, a colleague and disciple of Paulo Freire (Pedagogy of the Oppressed), developed Forum Theatre as a democratic, participatory, and collaborative production between the actors and the audience, to revolutionize traditional sit-and-watch theatre. Spectators in the audience become spect-actors, halt the oppressive element in a scenario, take the place of the actors, and eliminate oppression. The over-arching goal of Forum Theatre is to illuminate and achieve social justice.

Because of the frequent use of role-playing methodologies in clinical legal education, and its client-centered approach to legal representation, law school clinics are an ideal laboratory to develop and explore Forum Theatre as an instructional exercise. Students learn to interrupt oppression, to observe and check their own paternalistic instincts, to empower vulnerable clients, and to transform the legal encounter into one that is more ethical and just. Three scripts the authors have developed and used in clinical training are included as an Appendix.

"Theatre is a form of knowledge; it should and can also be a means of transforming society."

$$
\text { -Augusto Boal }
$$

Since its beginnings in ancient Greece, theatre has been intertwined with politics. ${ }^{1}$ From Sophocles, Euripides and Aristophanes, to the French Revolution, to Bertold Brecht's theatre of the proletarian revolution, theatre has often played a critical role in social transforma-

* JoNel Newman, Clinical Professor \& Director, Health Rights Clinic, University of Miami School of Law; Fergus Lawrie, Trainee Solicitor, MacRoberts, LLP; Donald Nicolson, Professor \& Law Clinic Director, University of Essex School of Law; Melissa Swain, Associate Director, Health Rights Clinic \& Lecturer in Law, University of Miami School of Law.

1 John Porter Lamberton, James P. Boyd \& Alfred Bates, The Drama: its History, Literature And Influence on Civilization I, at 27-29 (King Edward ed. London: The Athenian Soc'y) (1904). 
tions. ${ }^{2}$ Augusto Boal's Forum Theatre is a worthy successor to this tradition. ${ }^{3}$

We contend that Boal's Forum Theatre can also be a powerful tool in clinical legal education. This essay proceeds in three parts. First, we introduce Boal and Forum Theatre methodology. Second, we look at the role of Forum Theatre in education and review the relatively sparse literature on its use in legal education. Finally, we recount our experiences using this methodology in clinical legal training and offer some suggestions and conclusions for legal educators interested in trying this technique. We have also attached as an appendix a selection of scripts that we have developed and used in order to illustrate some of the points made and to provide examples for others to use as they see fit.

\section{Boal And the Theatre of the Oppressed}

Augusto Boal, the son of well-to-do liberal Portuguese parents living in Brazil, began writing and staging theatrical productions as a child in the family dining room in Rio de Janeiro. ${ }^{4} \mathrm{He}$ attended the University of Brazil and earned a degree in chemistry in 1952, but soon after left for Columbia University in New York to study theatre. 5 Boal returned to Brazil in 1955 and began working as a director and playwright at the innovative and politically progressive Arena Theatre in São Paolo. There, he began experimenting with various theatre methods, which he would later call "Theatre of the Oppressed," until he was forced into exile in $1971 .^{6}$ During the increasingly repressive

2 See Christian Meier, The Political Art of Greek Tragedy (1993); John Zumbrunnen, Aristophanic Comedy and the Challenge of Democratic Citizenship (2012); Peter J. Ahrensdorf, Greek Tragedy and Political Philosophy: RAtionalism and Religion in Sophocles' Theban Plays (2009); Susan Maslan, Revolutionary Acts: Theatre, Democracy, and the French Revolution (2005); Frederick Brown, Theater and Revolution: The Culture of the French Stage (1980); Margot Morgan, Politics and Theatre in Twentieth-Century Europe, at 49-50 (2013).

3 Ironically, with the exception of Bertold Brecht, with whom he aligns himself, Boal explicitly rejected the politics of the former theatrical "revolutionaries" mentioned above as coercive agents of the established system or as agents of the bourgeois struggle for political power. Augusto Boal, Theatre of the Oppressed 40-47, 65, 107-109 (Charles A. McBride \& Maria-Odilia Leal McBride trans., Theatre Comm. Group ed. 1985). Boal's Theatre of the Oppressed and Forum Theatre refer to the same theatrical methodology.

4 Frances Babbage, Augusto Boal 4-5 (2004).

5 Id. at 6; see also Aleks Sierz, Augusto Boal, The Guardian (May 5, 2009, 7:01 PM), https://www.theguardian.com/world/2009/may/06/augusto-boal-obituary. As a Columbia student in 1955, Boal impressively staged a play in New York: The House Across the Street. See id.

6 See Boal, Theatre of the Oppressed, supra note 3, at 159-190; BabBage, supra note 4, at 9-16; Martin Banham, The Cambridge Guide to Theatre 127-128 (1998); Doug Paterson, A Brief Biography of Augusto Boal, Pedagogy and Theatre of the 
military regime that began in the late 1960s, Boal and others at the Arena Theatre acted in outright defiance of the Brazilian government. As a result, Boal was arrested, tortured, and imprisoned for three months in 1971.7 Following national and international appeals on Boal's behalf, the government released him from prison, but sent him into exile. ${ }^{8}$ Boal remained in exile, living in Argentina, Portugal, and France, as he continued to develop his Theater of the Oppressed. He returned to Brazil after democratic rule was restored in $1985 .{ }^{9}$

While in exile, Boal published Theatre of the Oppressed in 1974. Here, he espoused his unique democratic theatre methodologies, including Forum Theatre. ${ }^{10}$ Boal's theatre methods, especially Forum Theatre, were premised on a simple principle: transforming traditional sit-and-watch theatre into a democratic, participatory, and collaborative production between the actors and the audience. ${ }^{11}$ The focus of Boal's theatrical theory was political and social. Its objective was transformative. ${ }^{12}$ Boal believed that in all arenas - whether in theatre, politics, or broader society - there is an oppressive force, party, or group, and an oppressed party or group. He thus created a theatrical method in which spectators in the audience become what he referred

OPPRESSED, http://ptoweb.org/aboutpto/a-brief-biography-of-augusto-boal/ (last visited May 12, 2017).

7 Augusto Boal, Hamlet and the Baker's Son: My Life in Theatre and Politics 284-90 (2001).

8 BABBAge, supra note 4, at 16; see also Paterson, supra note 6, and BANHAM, supra note 6 .

9 Bruce Weber, Augusto Boal, Stage Director Who Gave a Voice to Audiences, Is Dead at 78, N.Y. Times, May 9, 2009, https://www.nytimes.com/2009/05/09/theater/09boal.html (last visited December 31, 2019).

10 See Boal, Theatre of the Oppressed, supra note 3. Boal's work in Theatre of the Oppressed was heavily influenced by Paulo Freire's Pedagogy of the Oppressed. See Paterson, supra note 6 . Freire, a Brazilian educator, believed that a "dialogic exchange between teachers and students, where both learn, both question, both reflect and both participate in meaning-making" was the truest and most effective form of education. See Leslie Bentley, A Brief Biography of Paulo Freire, Pedagogy and Theatre of the Oppressed, http:// ptoweb.org/aboutpto/a-brief-biography-of-paulo-freire/ (last visited February 2, 2019); Boal took this educational premise and formed his own "dialogic exchange"-Forum Theatre-between actors and the audience. See BABBAge, supra note 4, at 19; see also Augusto Boal \& The Theater of the Oppressed, BRECHT FORUM, https://brechtforum.org/ abouttop (last visited May 12, 2017) ("[Forum Theater] is rooted in . . . the popular education method developed by educator Paulo Freire: (1) to see the situation lived by the participants; (2) to analyze the root causes of the situation, including both internal and external sources of oppression; (3) explore group solutions to these problems, and (4) to act to change the situation following the precepts of social justice."). Boal and Freire had a very close relationship; so close that, in response to Freire's death in 1997, Boal is reported as stating "I am very sad. I have lost my last father. Now all I have are brothers and sisters." See Paterson, supra note 6.

11 See infra notes 20-32 and accompanying text.

12 See id.; see also Levana Saxon, Tactic: Forum Theater, Beautiful Trouble, http:// beautifultrouble.org/tactic/forum-theater/ (last visited February 2, 2019). 
to as "spect-actors" - namely, spectators who enter the stage to take the place of another character in order to remove the oppressive element of the act. In this way, the audience gains agency and becomes empowered to identify oppression, and then to imagine and practice change.

Boal believed that acting out these changes would inform and help to change the audience and actors' daily political and social realities. ${ }^{13}$ While many of the scenarios involve overtly oppressive acts, Boal also discusses another successful objective for Forum Theatre exercises, and one that is especially well-suited to clinical legal education. That is the use of the methodology to rehearse, or "preview," the creation of a solution that empowers groups or individuals. ${ }^{14}$ In this type of scenario, Forum Theatre is used to develop a plan of campaign, advocacy strategy and tactics. Here, Boal uses the example of a group of residents from a particular neighborhood who decide to register a complaint with the city government and ask that the city resolve the problem. Who will do the talking? What arguments will they put forward? What can they expect from the other side? ${ }^{15}$ By acting through multiple scenarios, the group can perceive the current status quo and begin to imagine (and act upon) what it could become. ${ }^{16}$

Boal believed all theatre to be pedagogically oriented, but that most was pedagogic in the literal sense, replicating the didactic, abstract, uni-directional way parents and teachers teach passive child learners. ${ }^{17}$ His pedagogical goal for Forum Theatre was for actors and audiences to learn together through participating in interaction and collaboration rather than passive exposure to didactic monologue. ${ }^{18}$ The purpose of Forum Theatre was thus twofold: (1) to provide a democratic theatre space between the actors and the spect-actors; and (2) to empower the audience to strategize change in their daily lives, and act upon that strategy. It is the role of the intervening spect-actors to transform "the vision of the world as it is into a world as it could be." 19

13 See Paterson, supra note 6 ("[T]hrough this participation the audience members became empowered not only to imagine change but to actually practice that change, reflect collectively on the suggestion, and thereby become empowered to generate social action. Theatre became a practical vehicle for grass-roots activism.").

14 A similar methodology is discussed in the "Giving Voice to Values" pedagogy discussed infra at note 47 and accompanying text.

15 Augusto Boal, Games for Actors and Non-Actors 259 (Adrian Jackson trans., 2nd ed. 2002).

16 Augusto Boal, The Rainbow of Desire 13 (Adrian Jackson trans., 1995).

17 Cf. Frank S. Bloch, The Andragogical Basis of Clinical Legal Education, 35 V AND. L. REV. 321 (1982) (detailing the more active and experience-based nature of adult learning).

18 Boal, Games for Actors And Non-Actors, supra note 15, at 242.

19 Id. at 243. 


\begin{tabular}{lllll}
\hline |jciprod01 productn\N\NYCl26-2\NYC201.txt & unknown & Seq: 5 & 9-MAR-20 & 15:20 \\
\hline
\end{tabular}

\section{The Mechanics of Forum Theatre}

To fully appreciate the value that Forum Theatre can add to clinical legal education, and to use it most effectively, it is essential to have a fairly comprehensive understanding of this unique theatre method. Forum Theatre begins with actors performing an entire scenario without interruption during which one or more characters oppress another or others. Forum Theatre requires actors playing the part of the oppressor(s), and the part of the oppressed. ${ }^{20}$ In the legal context, for example, a lawyer might tell a client what to do without listening fully to the client's story or asking the client what he or she wants. ${ }^{21}$ Once the first run-through of the scenario is complete, it is acted out once again; only this time, spect-actors are encouraged to interrupt by shouting "stop." 22 When the scenario has been interrupted, the spect-actor who has shouted "stop" or "freeze" is invited on stage (or wherever the scenario is acted out) ${ }^{23}$ to take the place of the oppressor (or indeed the victim or a bystander) and complete the scenario by attempting to remove the oppressive element of the act, thereby changing the outcome and arc of the story. ${ }^{24}$ Other spect-actors sitting in the audience may then subsequently interrupt the action to replace the first spect-actor in order to further remove any remaining oppressive element. ${ }^{25}$ Alternatively, the spect-actor can return to the audience and the original actors continue from the point at which the oppression is resolved. This interrupt-and-replace cycle continues until the completion of the scenario or once all oppressive elements of the act are removed.

A facilitator called the "Joker" coordinates this process. ${ }^{26}$ The Joker begins the scene by explaining to the audience how Forum Theatre works. ${ }^{27}$ After the completion of the first run-through of the scenario without spect-actor intervention, the Joker explains the process

20 See id.; see also David Farmer, Forum Theatre, Drama Resource (Dec. 22, 2014), http://dramaresource.com/forum-theatre/.

21 See Boal, Games for Actors and Non-Actors, supra note 15, at 268-70.

22 This request is typically made by the spect-actor shouting "stop" or "freeze" from the audience. See id.; Consequently, Forum Theatre is sometimes also called Stop Start theatre. See, e.g. Forum Theatre or Stop Start Theatre, https://www.impactfactory .com/forum-theatre (last visited July 8, 2018).

23 See Additional Practical Suggestions, section V.B.4, below.

24 See Saxon, supra note 12.

25 See Farmer, supra note 20.

26 See The Role of the JoKer, http://handbook.actvise.eu/?page_id=24 (last visited June 29, 2018); see also Douglas L. Paterson, Theatre of the Oppressed Workshops, WeBSter's World of Cultural Democracy, http://www.wwcd.org/action/Boal.html (last visited May 12, 2017).

27 See Paterson, supra note 6; For a discussion of the "Rules" of Forum Theatre, see supra notes 20-26, and infra notes 28-32 and accompanying text. 


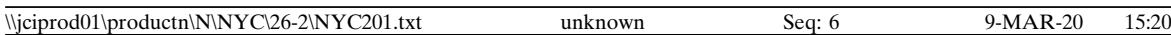

by which a spect-actor can replace an oppressive character. ${ }^{28}$ Once spect-actors intervene and complete their act(s), the Joker may follow up with questions designed to elicit audience and spect-actor reflection and participation, such as: "Why did you interrupt?," "What oppressive element were you trying to stop?," "Did the spect-actor effectively stop the oppression?" or "Can you do this in real life?" 29 The Joker may also stop an actor or a spect-actor during the scene to ask the actor or spect-actor to explain his or her reason for making a particular choice. Spect-actors are also encouraged to ask their own questions of the character. ${ }^{30}$ The Joker's role requires managing the logistics, leading the discussion, enforcing the rules of the game and asking salient questions, while being careful not to manipulate or influence the audience and avoiding all personal interpretations. According to Boal, the Joker "must always open the possible conclusions to debate, stating them in an interrogatory rather than an affirmative form [while constantly] relaying doubts back to the audience so that it is they who make the decisions." 31 Finally, the Joker assists the group with drawing conclusions and plans for how they will move forward based on the experience, as well as thanking and commending each spect-actor for their contribution. ${ }^{32}$

In addition to the logistics of Forum Theatre, the setting and subject matter of the scenario, and its relationship with the spect-actors is crucial. For example, if the audience is made up of lawyers, and they are watching a scenario portraying doctors and patients, lawyer members of the audience may well miss the point when a doctor mistreats the patient and thus fails to treat the patient effectively. The lawyers will thus be unlikely to interrupt the action and volunteer to engage in replacing the oppressive doctor character. However, if the audience is made up of lawyers watching a scenario portraying lawyers and clients, these audience members are much more likely be able to identify the point at which the lawyer behaves unethically toward his or her client, to interrupt and to replace the oppressive lawyer character. ${ }^{33}$

Similarly, the scenario must be well-crafted and conform to certain rules. It is essential to design scenarios that are possible to solve, rather than those that are hopeless in real life, as Forum Theatre's overarching goal is "to make breaches, to open up paths of liberation,

28 BoAl, GAmes for Actors And Non-Actors, supra note 15, at 260-62.

29 See Saxon, supra note 12.

30 Boal, Theatre of the Oppressed, supra note 3, at 186.

31 Boal, Games for Actors And Non-Actors, supra note 15, at 261.

32 The centrality and importance of the Joker is discussed above. See supra notes $26-$ 31 and accompanying text. See also, infra text accompanying notes 72-76.

33 BoAl, GAmes for Actors AND Non-Actors, supra note 15, at 261-62. 


\begin{tabular}{lllll}
\hline |jciprod01 productn\N\NYCl26-2\NYC201.txt & unknown & Seq: 7 & 9-MAR-20 & 15:20 \\
\hline
\end{tabular}

not drive people up against a wall of resignation." 34 Boal uses two examples of hopeless scenarios: a convicted prisoner who has been sentenced to death at the moment of his execution, and a woman alone in an underground station who is attacked by four armed men. In these scenarios, he cautions, spect-actors are unlikely to be able to realistically intervene to stop what he defines as aggression. Rather, he suggests, an earlier scenario could be created. How might the prisoner have avoided a death sentence? How might he have chosen not to commit a crime? What might the woman have done rather than take the underground alone late at night? What security measures might the station have decided to provide? Forum Theatre requires alternatives and choices that can liberate its subjects. ${ }^{35}$

\section{Forum Theatre's Use in Educational Settings}

Forum Theatre has regularly been used as a workshop tool in theatre and theatrical education. ${ }^{36}$ In recent years, it has been used as an educational tool for professionals, notably in the medical profession, in universities, as a general education tool in schools, and in social justice training. ${ }^{37}$ However, its use in training and educating lawyers and law students is still a novel concept, and its use in clinical legal education is unknown. The scant descriptions of Forum Theatre found in legal literature appear primarily in the context of educating community groups, grass roots organizing, or work being done with oppressed individuals, such as domestic violence victims. ${ }^{38}$ There are

34 Id. at 254.

35 Id. at 254-56.

36 See, e.g., Theatre OF The OpPressed NYC, http://www.tonyc.nyc/workshops (last visited May 12, 2017); Carmel O'Sullivan, Searching for the Marxist in Boal, 6 ResearCH in Drama Educ. 85-97 (2001); Chrissie Poulter, Playing the (Power) Game, 3 Contemp. Theatre Rev. 9 (1995); Mady Schutzman \& Jan Cohen-Cruz, Playing Boal: TheaTRE, Therapy, ACTIVISM (1994).

37 See, e.g., Michael Shank, Redefining the Movement: Art Activism, 3 SeAttle J. FOR Soc. Just. 531 (2005) (promoting use of methods such as forum theatre for conflict resolution); Kaitlen M. Osburn, Forum Theatre: Empowering Students to Speak, Act, and Know, (unpublished B.A. thesis, Western Kentucky University 26-48 (2010) http://digitalcommons.wku.edu/stu_hon_theses/245; Katelyn Sadler, Art As Activism and Education: Creating Venues for Student Involvement and Social Justice Education Utilizing Augusto Boal's Theater of the Oppressed, 31 The Vt. Connection Journal 82 (2010); Theatre of the OpPressed IN THE Medical Humanities, http://www.ccdc.in/theatre-oppressed-medicalhumanities (last visited May 12, 2017); Ravi Ramaswamy, Theatre of the Oppressed and Children, Centre for Community Dialogue and Change, http://www.ccdc.in/theatreof-the-oppressed-and-children (last visited May 12, 2017); THEATRE OF THE OPPRESSED IN EDUCATION, http://www.ccdc.in/theatre-oppressed-in-education (last visited May 12, 2017); Forum Theatre Workshop, http://www.thejusticetheaterproject.org/forum-theatreworkshop-april-21-22/ (last visited May 12, 2017).

38 See, e.g., Jaclyn Booton and Paul Dwyer, Legal Theatre: A Theatre-based Approach to Community Legal Education (2006), http://www.lawfoundation.net.au/ 


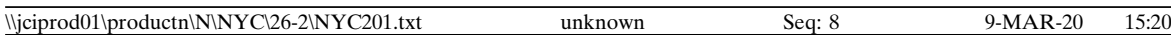

tantalizingly few references to its potential in the training of lawyers, and none in clinical legal education.

Among the few references in legal literature to Forum Theatre's capacity to educate lawyers is in Lucie White's 1989 case study of a group of homeless activists and their lawyers who undertook a Forum Theatre project ancillary to welfare rights litigation in Los Angeles. ${ }^{39}$ White describes a homeless theatre group, the Los Angeles Poverty Department (LAPD), founded by John Malpede, a performance artist and a paralegal for the Los Angeles Legal Aid Foundation's Homeless Litigation Unit. The actors in the project had all experienced homelessness themselves, and been exposed to poverty, isolation, mental illness, violence and incarceration. Many remained homeless or faced the threat of homelessness. ${ }^{40}$ The actors were also clients of the Inner City Law Center seeking solutions to their welfare problems, and had provided affidavits in various class action lawsuits that had been filed on their behalf. White suggests that Forum Theatre may have the capacity to both empower the homeless members of the acting group as well as to educate their advocates:

[For] advocates and allies, who come expecting to see disciplined, comprehensible political theater - giving back to them all of the assumptions about the homeless they already held - the experience is one of disruption. . The connection of this theater to the advocacy effort, at least in its current early stage of development, is very attenuated. But two themes emerge. . . the theater can help change [the homeless'] often harsh images of themselves, empowering them to see their own capacities and identify their needs. An equally important potential of the theater is to give advocates, other allies of the homeless, and the more general public some sense of how some homeless people experience the world. . . By shaking up the lawyers' images of who their clients are, the theater experience might open them to a more genuinely collaborative approach to their own

ljf/lawed15.nsf/9f2043ee7ccfa2ddca256f1200115808/8d19068db99e3d7cca25720c000aac3f/ \$FILE/LegalTheatreRpt06.pdf (last visited December 31, 2019) (reporting on an experiment with Forum Theatre as a means for community education and development among recently arrived migrants and refugees in New South Wales, Australia); Beth Osnes, Engaging Women's Voices for Energy Justice, 21 Colo. J. Int'L EnVtl. L. \& Pol'y 341, 344 (2010) (identifying strategies to use Forum Theatre as a tool to engage communities in appropriate sustainable energy development projects); Lani Guinier, Supreme Democracy: Bush v. Gore Redux, 34 Loy. U. CHI. L.J. 23, 63-64 (2002) (raising the possibility of using Boal's Forum Theatre methodologies for expanding democracy through constituent involvement based on work Boal did as an elected official); Carrie Cuthbert \& Kim Slote, Second Panel: Bridging the Gap Between Battered Women's Advocates in the US and Abroad, 6 Tex. J. Women \& L. 287, 292 (1997) (describing use of Forum Theatre with domestic violence survivors).

39 Lucie White, Mobilization on the Margins of the Lawsuit: Making Space for Clients to Speak, 16 N.Y.U. Rev. L. \& Soc. Change 535, 557-563 (1989).

40 Id. at 559. 


\begin{tabular}{lllll}
\hline |jciprod01 productn\N\NYCl26-2\NYC201.txt & unknown & Seq: 9 & 9-MAR-20 & 15:20 \\
\hline
\end{tabular}

work. ${ }^{41}$

We have located three other legal academics who discuss using Forum Theatre in legal education, though none specifically in the clinical context. Peggy Cooper Davis of NYU Law School has reported using Forum Theatre to train law students. ${ }^{42}$ She has also collaborated with theatre professionals to use process drama (which shares some characteristics with Forum Theatre) as a teaching tool in the law school classroom. ${ }^{43}$ She and James Webb describe their work with process drama in teaching law students in terms that resonate with adult learning theory ${ }^{44}$ and in particular David Kolb's insightful conceptualization of the learning circle. ${ }^{45}$ In the past year, Davis reports that she has been experimenting with Forum Theatre techniques in collaboration with educational theatre colleagues. ${ }^{46}$

Vivien Holmes, who teaches at Australian National University has compared Forum Theatre's methodology with the performative aspect of 'Giving Voice to Values' (GVV) pedagogy developed by Mary Gentile and which Holmes recommends as a way of introducing students to behavioral ethics and encouraging them to act on their values when confronted with an ethical challenge. ${ }^{47}$

[GVV] functions within what some ethicists call a 'performative space' focusing on the 'communicative activity involved in creating and shaping moral futures,' and helping to develop moral imagination. This performative aspect of GVV links it to traditions of Augusto Boal's Theatre of the Oppressed, in which the audience members become active in a play, re-imagining and re-enacting

41 Id. at 562-63.

42 Peggy Cooper Davis, What Does Documentary Filmmaking Have to do with Practicing Law? 8 U. Md. L.J. Race, Religion, Gender \& Class 7, 14-15 (2008).

43 Peggy Cooper Davis \& James Webb, Learning from Dramatized Outcomes, 38 WM. Mitchell L. Rev. 1146 (2012). Process drama, an experimental theatre method, shares some characteristics with Forum Theatre, using theatre in nontraditional, experiential ways to encourage active learning. It seeks to "train students to think from within a dilemma rather than talking about the dilemma." Id. at 1148-49.

44 See Bloch, supra note 17.

45 Cooper Davis and Webb state:

Process drama, like much experiential pedagogy, involves cycles in which students try something (act), think about what they did (reflect), and draw lessons from their reflection (conceptualize). The cycle then begins again as students apply their conceptualizations while trying something new. The beauty of these experiential methods is that the outcomes of student effort are not just indicators of learning progress, but also-and more importantly—subjects of perpetual study.

Cooper Davis \& Webb, supra note 43, at 1147. Cf. David A. Kolb, Experiential Learning: Experience as the Source of Learning and Development (1984).

46 Email to JoNel Newman from Peggy Cooper Davis (June 7, 2018) (On file with author).

47 Vivien Holmes, 'Giving Voice to Values': Enhancing Students' Capacity to Cope with Ethical Challenges in Legal Practice, 18 Legal Ethics 115, 127 (2015). 


\begin{tabular}{lllll}
\hline |ljciprod01\productn\N|NYCl26-2\NYC201.txt & unknown & Seq: 10 & 9-MAR-20 & 15:20 \\
\hline
\end{tabular}

scenes in line with their own values. ${ }^{48}$

Finally, Gillian Calder, who teaches at the University of Victoria in British Columbia has developed Forum Theatre scenarios that focus on using Boal's dialogic techniques to engage incoming first year law students in a critical examination of the law school classroom climate. ${ }^{49}$

But what does Forum Theatre offer for law school clinics? Its enormous potential is explored below.

\section{Forum Theatre's Potential for Clinical Legal Education}

We believe that Forum Theatre should be a more widespread training practice in university legal education in general, as well as in continuing legal education, advocacy and even judicial training, and not just clinical legal education. Forum Theatre offers prospective and practicing lawyers an excellent opportunity to identify oppression in legal settings, to interrupt it, to observe and check their own paternalistic instincts, to empower vulnerable clients, and to act in other more ethically informed ways. ${ }^{50}$ Forum Theatre has the capacity to expose oppressive lawyer-client dynamics and other ethically dubious behaviors, to educate lawyers, and clinical students and legal educators about those behaviors, and to transform their future practices.

Because of the already frequent use of role-playing methodologies in clinical legal education, as well as its client-centered approach to legal representation, law school clinics are an ideal place to fully explore and develop Forum Theatre as an instructional exercise for lawyers. Clinical pedagogy has long focused simultaneously on "the needs of clients and students." 51 At the same time, it seeks to "advance the students' understanding of justice" 52 and the ethics of legal

48 Id.

49 Gillian Calder, Performance, Pedagogy and Law: Theatre of the Oppressed in the Law School Classroom, in The Moral Imagination And the Legal Life: Beyond Text in Legal Education, (Zenon Bakowski \& Maksymilian Del Mar eds., 2013).

50 Although not the focus of this essay, judges can and should be confronted with the oppressive and patronizing treatment of court actors as well as with the conduct, language, tone of voice and demeanor that more subtly control and influence proceedings. We believe that Forum Theatre has the capacity to change oppressive treatment by the tribunal into more democratic exercises, and hope to establish a dialogue with jurists who may be inclined to consider this methodology in the future.

51 Wallace J. Mlyniec, Where to Begin? Training New Teachers in the Art of Clinical Pedagogy, 18 Clin. L. REv. 505, 537 (2012).

52 Id. at 543; See also Jane Harris Aiken, Striving to Teach "Justice, Fairness, and Morality", 4 Clin. L. Rev. 1-64 (1997); Steven Wizner \& Jane Aiken, Teaching and Doing: The Role of Law School Clinics in Enhancing Access to Justice, 73 FordHAm L. ReV. 997, 1005 (2004); Donald Nicolson, Legal Education, Ethics and Access to Justice: Forging Warriors for Justice in a Neo-Liberal World, 22 INT'L J. Legal Prof. 1 (2015). 
practice. ${ }^{53}$ To accomplish these aims, clinical pedagogy relies heavily on putting clinical law students in the role of lawyer. ${ }^{54}$

For instance, in introducing Forum Theatre methodology to their students, clinical educators could begin by staging a lawyer-client meeting in which the lawyer behaves unethically and oppressively in multiple ways - the lawyer shares confidential information about other clients in the meeting, ignores or talks over the client, and instructs the client to pursue a legal strategy that will compromise her rights but be easier for the lawyer, all without taking the time to explain all the options and their ramifications to the client. Students are then challenged by asking them to consider questions like: Could you do a better job? How? What oppressive conduct of the lawyer will you remedy? Would the situation benefit from you being able to stop the lawyer's unethical and oppressive conduct and replace the lawyer inrole? Could others gain by watching you replace the lawyer, and by watching you conduct the meeting in a more ethical and less paternalistic manner? Would you and others gain if another person subsequently replaced you to remedy your own oppression? ${ }^{55}$

Scenarios such as this exemplify the value that the principles and methodologies underlying Boal's Forum Theatre can bring to clinical legal education and the education of law students and lawyers more generally. By witnessing oppressive or otherwise unethical behavior, members of the audience identify the problematic behavior, interrupt it, and then construct and carry out a better strategy in their interac-

53 See e.g. Donald Nicolson, Education, Education, Education: Legal, Moral and Clinical, 42 The Law Teacher 45-173 (2008); JoNel Newman \& Donald Nicolson, A Tale of Two Clinics: Similarities and Differences in Evidence of the "Clinic Effect" on the Development of Law Students' Ethical and Altruistic Professional Identities, 35 Buff. Pub. INT. L.J. 1 (2017); Nigel Duncan, Ethical Practice and Clinical Legal Education, 7 INT'L J. OF Clin. Legal Educ. 7 (2005); Nina W. Tarr, Ethics, Internal Law School Clinics, and Training the Next Generation of Poverty Lawyers, 35 WM. Mitchell L. Rev. 1011 (2009); Anthony V. Alfieri, Teaching Ethics/Doing Justice, 73 Fordham L. Rev. 851 (2004); Julian Webb, Conduct, Ethics and Experience in Vocational Legal Education: Opportunities Missed, in Ethical Challenges to Legal Education and Conduct (K. Economides ed., 1997).

54 See, e.g. Carolyn Grose, Beyond Skills Training, Revisited: The Clinical Education Spiral, 19 Clin. L. Rev. 489, 499 (2013):

In the clinical experience, the student assumes a role, learns the obligations of the role, recognizes certain cues involved in assuming that role, and ultimately acquires the aptitudes required to perform the role. More than simply embodying the role of a lawyer representing clients, however, the clinical method helps students reflect on and learn from that role assumption.

55 To return to a possible judicial training scenario, Forum Theatre dramatizations might ask judges and others to learn from the dramatization of court proceedings in which the judge character speaks to witnesses or parties in a condescending or contemptuous manner. The audience can be asked how they might replace the judge character and strike a different tone in the courtroom. How would others be affected by having the judge's oppression recognized, halted and replaced? 
tions with clients. By taking the place of the oppressive individual such as the paternalistic lawyer in the above scenario, spec-actors must act out a strategy, which can be critiqued or re-played by other members of the audience. ${ }^{56}$

Indeed, one does not need to limit the use of Forum Theatre to exploring issues of oppression, justice and ethics. We have found that it can be an engaging and memorable way of teaching legal skills. ${ }^{57}$ Because all lawyer-client relations contain the potential for oppressive and unethical behavior, as our scripts reproduced in the Appendix illustrate, Forum Theatre provides an excellent way of combining skill development with ethical awareness and practicing ethical and nonoppressive behavior. ${ }^{58}$

\section{Our Experiences And Recommendations}

The authors first became interested in and aware of Forum Theatre's potential after Donald Nicolson, one of the authors, attended the Global Alliance for Justice Education (GAJE) conference in Delhi in December 2013. Tired and hot, he reluctantly attended a "cultural evening" after a demanding conference day and was blown away by two Forum Theatre performances by local students on domestic violence and sexual harassment. Although these were designed for community education, it struck him that Forum Theatre might provide an effective vehicle for legal education and shortly afterwards he experimented with it while teaching Irish law graduates who were taking a professional course on ethics. For reasons discussed below, the experiment was less than wholly successful, but the clinical exchange program between the University of Strathclyde Law Clinic and the University of Miami Health Rights Clinic launched in 2014 provided another opportunity to experiment with Forum Theatre, this time in the clinical context. ${ }^{59}$

The exchange model requires, among other things, that students from the two different clinics work together on a joint project to be presented at the conclusion of the program. Nicolson recommended that one of the student teams consider developing a Forum Theatre model for training incoming law student clinicians in client interviewing and counseling, and in the ethical issues involved.

Having learned from his Irish experience that persons unfamiliar with Forum Theatre would benefit from seeing it before being asked to participate, Nicolson sought a topically suitable or compelling illus-

56 See generally BoAl, TheAtre of the Oppressed, supra note 3.

57 See supra notes 20-32 and accompanying text.

58 BoAl, GAmes for Actors And Non-Actors, supra note 15, at 254-56.

59 For a description of both clinics see Newman \& Nicolson, supra note 53. 
tration to show the students, but with little success. The best he could find was a YouTube video depicting an awkward scene at a dinner party performed by students at Mount Royal University in Calgary, Canada that was designed to explore the etiquette of promoting ethical values in social interaction. ${ }^{60}$ Nonetheless, with Boal's concept in mind, two students who had taken up this project, co-author Fergus Lawrie from Strathclyde and Dede Akiti, a student from Miami, created a script and presented a Forum Theatre exercise that worked brilliantly for both clinics in the teaching of initial client interviewing skills and ethics to incoming students. Since then, both clinics have incorporated at least one Forum Theatre exercise in their training for incoming clinicians. We include three different scripts and discuss them below.

\section{A. The Scenarios We Have Developed}

\section{The "Vulnerable Client" Scenario 61}

The first scenario is the adaptation of the original script Fergus and Dede presented as part of the clinical exchange program in 2015. This script presents an all-too-easily-imagined scenario in which an unprepared and seemingly indifferent law student clinician unthinkingly waives client confidentiality at the initial interview of a prospective client. The student exhibits little patience with the client, who is vulnerable and has limited English proficiency, and instead speaks directly to the client's neighbor who has brought the client to the clinic. At the end of the encounter, the student improperly provides the client (or, rather, the neighbor) with legal advice. In a heavy-handed and paternalistic manner, the student then tells the client what legal course the client should pursue without having adequately explained the various options or ascertaining what the client prefers.

The first version of the Vulnerable Client scenario was presented at the University of Strathclyde in the spring of 2015. Fergus acted as the Joker, Dede as the law student clinician, and two other Strathclyde Law Clinic students played the roles of the prospective client and the neighbor. The students and faculty from both clinics immediately appreciated how useful this methodology was for training clinical students. The students were instantly engaged and anxious to interrupt in order to improve on the performance of the clinical student at virtually each juncture of the interaction with the client. Indeed, it took a

60 Alej Duke, An Example of Forum Theatre, Youtube (Oct. 26, 2009) https://www .youtube.com/watch?v=NbYx01re-ec; see Playlist in Forum Theatre, http://www .bbc.co.uk/schools/gcsebitesize/drama/activities/forum_theatre/forum_theatre.shtml (last visited July 06, 2018) (providing a good example of the dynamics of Forum Theatre).

61 See Appendix, Script 1. 


\begin{tabular}{lllll}
\hline |ljciprod01\productn\N\NYCl26-2\NYC201.txt & unknown & Seq: 14 & 9-MAR-20 & 15:20 \\
\hline
\end{tabular}

lot of restraint on the part of co-authors to refrain from intervening themselves!

In Miami, the first Health Rights Clinic class (on interviewing and counseling), is devoted to a Forum Theatre exercise that has been derived from this initial script. ${ }^{62}$ This version has also been used to demonstrate the value of Forum Theatre at clinical conferences in $\mathrm{Ca}$ nada and England and at a workshop for clinical law students at Trinity College Dublin. 63

\section{The "Porn Star Interview" Scenario ${ }^{64}$}

At the University of Strathclyde, Fergus developed a more elaborate script for use in the Strathclyde Law Clinic's required induction training on client interviewing. This scenario, which was based on an actual Strathclyde Clinic case, is also now used at the University of Essex, where Law Clinic staff have enthusiastically embraced their new role as thespians and have made alterations to the script.

In the Porn Star Interview, the actual case has been exaggerated for comedic effect. As in the Vulnerable Client scenario, the law student is disengaged and unempathetic, but the prospective client is a nervous teacher who has been dismissed, as it turns out, for participating in an "adult movie" when short of cash as a student. The law student advisor is incredibly discourteous, interrupting the interview to shout at the advisor's assistant and taking (confidential) phone calls. The law student forgets to show the client out of the room and does not even say goodbye. The law student is also patronizing and unsupportive, involuntarily laughing when the client discloses the reason for the client's dismissal. Moreover, the law student speaks in legalese, make assumptions about what the client wants, assumes the best way forward for the case without consulting the client and conveys a false sense of security about the case's success, while also breaching clinical rules in giving advice without a supervisor's review.

62 See Angela Morris, High Drama Comes to University of Miami Law School Clinic, DAIly Business Review (Oct. 13, 2017, 5:12 PM), https://www.law.com/dailybusinessre view/almID $/ 1202800421783 /$ ? $\operatorname{code}=1202617073880 \&$ curindex $=4 \&$ curpage $=2 \&$ slreturn $=20190005104042$ (last visited February 15, 2019).

63 Donald Nicolson, JoNel Newman, Melissa Swain \& Fergus Lawrie, Using Forum Theatre to Teach Skills, Values and Ethics, https://www.northumbria.ac.uk/-/media/files/ad vancement/ijcle-2017-session-abstracts-with-chairs-and-rooms-final.pdf?la=en\&hash=45 DE277D8D5F8D95B7BF579E554F915265863ECD (last visited February 15, 2019); Sarah Bujold, JoNel Newman, Melissa Swain, Fergus Lawrie \& Lyndsay Monaghan, Teaching and Learning Ethics Through A Clinical Exchange, https://www.northumbria.ac.uk/aboutus/academic-departments/northumbria-law-school/law-research/legal-education-and-pro fessional-skills/ijcle-2016-presentations/ (last visited February 15, 2019).

64 Appendix, Script 2. 
\begin{tabular}{lllll}
\hline |jciprod01 productn\N\NYCl26-2\NYC201.txt & unknown & Seq: 15 & 9-MAR-20 & 15:20 \\
\hline
\end{tabular}

\section{The "Wrong Client" Scenario ${ }^{65}$}

The authors adapted another more complicated Strathclyde Clinic case for use in teaching ethics whilst training law clinic students in Hamburg, and then further tested it with clinical students and candidate attorneys ${ }^{66}$ in South Africa. The script was then modified to mitigate the problems discussed below and is now used to test students on what they have learned from an introductory class on ethics during clinic induction training. Admittedly, the issues are relatively complex and certainly there are no easy answers. However, the aim is not to test whether the students know the "right" answer to the issues raised (if indeed there are such right answers). Instead, it is to see whether they can identify the ethical issues that they have been taught and to show them how easy it is to miss them if their ethical "antennae" have not been primed. Moreover, the problems can also be used at more advanced levels to test how students might resolve the ethical problems.

The case involves an initial interview of an employee of a housing shelter charity who approaches a lawyer to see whether a contract that the employee mistakenly entered into on behalf of the charity can be rescinded. The employee is worried about being dismissed or otherwise disciplined and further reveals that she strongly suspects that a member of the charity's board of directors has behaved inappropriately with children staying at the shelter. When the employee intimates that she does not want to report these suspicions, the lawyer threatens to do so herself and uses emotive rhetoric in order to persuade the employee to go to the authorities. The Wrong Client scenario is designed to lead to a discussion about confidentiality and lawyer control. However, the scenario also challenges students to identify the potential conflict of interest between the lawyer being asked to advise the employee as an agent of the charity, and advising the client in her own right as an employee.

\section{B. Our Recommendations}

Based on our experiences with these scenarios in various iterations, and the feedback we have received from participants when we have tried them out in our law clinics, at conferences and workshops, we make a number of suggestions to clinical legal programs interested in incorporating Forum Theatre into their training.

65 Appendix, Script 3.

66 I.e. those taking their articles of clerkship in order to qualify. 


\section{Develop A Scenario That Meets Your Needs}

The clinic should develop a scenario that fits its own unique educational needs and addresses issues likely to be encountered in the clinic. The scenario should also consider the students' level of training. And, of course, the scenario should involve forms of oppression or other ethical or practical problems that are resolvable. As Boal discusses, ${ }^{67}$ it is essential that the clinical students who are spect-actors be able to "fix" the situation or the exercise will be unsuccessful.68 This does not require a single solution, however, as one useful part of the training can be students observing various ways that different individuals can resolve the problem. On the other hand, some scenarios may be too complex for resolution by early learners. For example, in the Wrong Client scenario, the ethical issues raised by lawyer paternalism and client conflicts may be too open-ended and complex to be readily resolved by a student spect-actor. This scenario may be better suited to audience discussion rather than interruption and intervention, or to intervention only by spec-actors who have more extensive training and experience than neophyte law clinic students. ${ }^{69}$ For similar reasons, it is necessary that the legal advisor in this scenario be played by someone with detailed knowledge of legal ethics so that they extemporize as necessary to explore the many, subtly different, ways of dealing with the same ethical problems.

On the other hand, the solution to some issues in the scenarios we have scripted are so obvious or practical that they do not lend themselves particularly well to theatre. For instance, there is little dramatic benefit gained from a spect-actor intervening simply to switch off a phone that interrupts the client interview, though it does serve as a powerful reminder to students who often forget to disconnect from their phones. Encouraging student spect-actors to interrupt in order to clear up a messy desk is more effective as pedagogical theatre, but even better is prompting them to rearrange the seating of lawyer and client. This can be finessed by more than one spect-actor disagreeing with the first intervention, and can lead to a useful discussion of the implicit message conveyed by side-by-side versus face-on seating, the use or non-use of desks, etc. The contrast between the Vulnerable Client and the Wrong Client scenarios can thus be best understood as reflecting different skill levels and experiences among the intended spect-actors.

The Vulnerable Client interview scenario reflects a pedagogical

\footnotetext{
67 See Boal, Games for Actors and Non-Actors, supra note 15, at 254.

68 See id.

69 See id at 261-62.
} 
choice to use a basic scenario requiring a minimum number of players to train incoming students with no clinical or real-world legal experience to do initial interviews with potential clients. This scenario requires a Joker and a cast of three persons: a student clinician, a prospective client and a neighbor who accompanies the client.

Because Miami students, in particular, often interview and work with clients who have limited English proficiency, the script involves a potential client who speaks limited English accompanied by a bilingual neighbor who is ostensibly helping the client with her problem. While in this scenario, the neighbor appears unexpectedly at the interview to "help" by interpreting for the prospective client, the dynamic would work equally well with any third person - spouse, friend or relative - who wants to "assist" in the interview, irrespective of language proficiency concerns.

The arrival of the unexpected third person to participate in the interview immediately creates an ethical dilemma for the student as well as a client relations problem. At the point this scenario is introduced in Miami, the clinic students have not yet conducted or observed any interviews, and have had only an orientation training that covers the ethics of client communications and confidentiality. The principles of confidentiality, third parties, and the possibility that such third parties may be covered by privilege and confidentiality under certain limited conditions have been briefly covered, but synthesizing and applying these concepts in real time is a challenge..$^{70}$ The students often find it difficult to convey these fairly complicated legal constructs to a client and "friend," especially without giving offense. At orientation they have been instructed to make every effort to speak to clients alone, at least long enough to ascertain whether there seems to be any coercion or undue influence, and to get the client's authorization to resume with any unexpected third party. Each new student spect-actor who interrupts and takes over at the threshold of the interview scenario manages this better and more tactfully, learning from and improving upon the performance of the previous student spectactor who intervened.

The Vulnerable Client scenario concludes with the law student improperly accepting the case and giving legal advice not sanctioned or reviewed by the supervising attorneys. This is impermissible under

70 Orientation training on these topics includes, inter alia, an introduction to Model Rule of Professional Conduct 1.6, Confidentiality of Information, a discussion of attorneyclient privilege and the extent to which confidentiality and privilege can apply to third parties, as well as a discussion of the law governing formation of the attorney-client relationship to ensure students do not inadvertently create an attorney-client relationship in interviewing potential clients. Health Rights Clinic Orientation, PowerPoint slides on file with author. 
Florida's ethics rules and those of the clinic. The student also behaves paternalistically and is overbearing, failing to consider (or even ask about) the client's goals. These are basic but important issues that virtually all law students are able to recognize when they see them. Miami clinic students report that they feel more comfortable and perform better at client interviews after having had this opportunity to practice and observe. ${ }^{71}$

Subject matter choices in the scenarios also affect student spectactor participation. In contrast to the fairly straightforward Vulnerable Client scenario, Nicolson attributes a major reason for the failure of his first experiment with Forum Theatre in Ireland to his choice of subject matter. Wanting to test the students' grasp of the ethics of advocacy, he set up a scenario involving a rape case. Unfortunately, many of the students were made uncomfortable by the tactics of the defending lawyer character who was asked to use sexist cross-examination, or they regarded the topic as too controversial or sensitive to be willing to intervene and participate. In response to this problem of subject-choice and in order to increase the sense of verisimilitude, the authors have opted to use actual clinic cases in developing scenarios, as is the case with the second and third scripts in the Appendix.

Other initial choices are important to encourage participation. One choice that the authors have made - particularly in the more basic first and second scripts - is to exaggerate the student clinician's inattention to ethics, basic good manners, and developing a good client relationship. This serves two purposes. First, it provides some comic relief and draws the other students into the exercise. Second, because the errors and omissions are quite glaring and all the students know that they can do better, they are encouraged to intervene and try their hand at remedying the problem.

\section{Keep In Mind The Joker's Importance}

The role of the Joker in explaining and enforcing role-play rules highlights the importance of the rules and the Joker in the success of using Forum Theatre as an educational tool. ${ }^{72}$ The Joker should know the script inside and out, understand exactly what the goals of the exercise are, what issues need to be highlighted, the relevant concepts, and potential resolutions. The Joker should also be comfortable guiding a discussion without taking over or pushing any particular resolution or point of view, and make others comfortable coming on stage and speaking. ${ }^{73}$ Unlike the other cast members, who usu-

\footnotetext{
71 See Morris, supra note 62, at 2.

72 See discussion supra notes 26-32 and accompanying text.

73 See Augusto Boal, Legislative Theatre: Using Performance to Make
} 


\begin{tabular}{lllll}
\hline |ljciprod01\productn\N\NYCl26-2\NYC201.txt & unknown & Seq: 19 & 9-MAR-20 & 15:20 \\
\hline
\end{tabular}

ally $^{74}$ have only to play their scripted parts, and have an opportunity to rehearse, the Joker's work is unscripted and extemporaneous, except for the initial explication of the exercise and its rules. Thus, the Joker's role depends very much on the discussion and actions of the spect-actors. In addition, the Joker may be called upon to enforce a rule during the scenario. For example, our Jokers often have to stop spect-ators from intervening on the first run-through of the scenario because many get carried away and shout "stop" during the initial presentation. Boal describes the Joker as:

magical, omniscient, polymorphous, and ubiquitous. On stage he functions as a master of ceremonies, raisonneur, kurogo, etc. He makes all the explanations, verified in the structure of the performance, and when necessary, he can be assisted by the coryphaeus or the choral orchestra. ${ }^{75}$

At the same time, the Joker must:

watch out for "magical" solutions, i.e., solutions that would not be possible or have the effect shown in reality. S/he can interrupt an actor's performance if he considers it as magical - not by ruling that it is magic but instead by asking the spect-actors to decide if the solution is possible. ${ }^{76}$

In short, the Joker's role is the most central, difficult, and important to the success of any Forum Theatre exercise.

Because author Fergus Lawrie had played the Joker's role in the original scenario in Glasgow so well and so naturally, upon returning to Miami, authors Newman and Swain failed to appreciate the centrality of the Joker's role and on more than one occasion failed to properly work with and prepare a student for the role. It was only after working with Lawrie again at a workshop for Trinity students in Dublin that they fully appreciated how incredibly important a properly prepared Joker is to its success. If students are to play the Joker, we recommend spending significant time with them to discuss goals, possible outcomes, questions that might be raised and to ensure they are familiar with, and able to explain, Forum Theatre methodology. By contrast, Nicolson prefers to act as the Joker himself in that this is less time-consuming, and UK clinic students are younger and hence likely to be less confident than their US counterparts.

Politics 46 (1998).

74 But see the discussion of the legal advisor in the Wrong Client scenario supra note 65 and accompanying text.

75 Boal, Theatre of the Oppressed, supra note 3, at 182.

76 See The Role of the Joker, supra note 26. 


\section{Develop And Adapt Rules And Scripts As Needed}

As discussed above, Forum Theatre comes with certain rules of play, among them that the audience initially watches the scenario played through without interruption and the Joker can interrupt a spect-actor who may be creating a "magical" solution, etc. ${ }^{77}$ In the course of using the Vulnerable Client scenario, we also found that we needed to make additional rules for the Joker to explain at the outset and to later enforce. First, we set a rule that it is only the student clinician whose character can be replaced by a spect-actor. In the Vulnerable Client script, the neighbor is somewhat overbearing and behaves paternalistically toward the client. While the purpose of our exercise was to train law student clinicians, we found that some students wanted to take over the role of the neighbor in order to make that role less oppressive. It is also possible that students might want to play the client in a way that removes the embedded problem, thus requiring an awkward winding back to the original script. ${ }^{78}$ Since our focus is on training law students to act as law clinicians in a given situation, we found we needed to explicitly limit them to substituting for the law student cast member.

Along the same lines, in the Vulnerable Client scenario we found that we needed to establish a rule at the outset that a professional interpreter was not available. We wanted to train students to work within the scenario that confronted them. However, when we first demonstrated this methodology to other clinical educators, we found that many of our clinical colleagues were inclined to stop the action and call for an interpreter. ${ }^{79}$ Further, in Miami, bilingual students often assumed the role of the law student and thus "solved" the communications problem. Both of these solutions violate Boal's rule against "magical solutions." 80 Another way to resolve this would be to adapt the script so that instead of limited English proficiency the vulnerable client has a mild cognitive impairment.

\section{Additional Practical Suggestions}

We believe that students will derive more from a Forum Theatre exercise if they have some understanding of Boal's method before they begin. While the Joker's introduction, explanation and statement

77 See $i d$.

78 E.g., in the scenario in Appendix 3, they might simply volunteer to go to the police about the sexual abuse thus removing any possible lawyer manipulation of the client to persuade them to do so.

79 Sarah Bujold, JoNel Newman, Melissa Swain, Fergus Lawrie \& Lyndsay Monaghan, supra note 63.

80 BoAl, Games for Actors ANd Non-Actors, supra note 15, at 261-62. 
of the rules is sufficient if one is pressed for time, our experience is that students are more willing and anxious to participate in the scene if they have been introduced to Forum Theatre and its background in advance. This can be accomplished through assigning readings on Boal and Forum Theatre and/or by providing a demonstration that can be live or filmed. We recommend both if time permits.

When you are developing a scenario, we also recommend that you give thought to how many cast members are required, so that you avoid creating a scenario for which the clinic has insufficient experienced players to perform. While the Joker's familiarity with the scenario and methodology is paramount, the scenario will also be more effective if all the players have some familiarity with the method and the script, have had a chance to rehearse in advance, and also have the necessary skills to ad lib where less fully developed scripts are used, such as the Wrong Client scenario.

Another suggestion is to number the lines of the script. When done well and the spect-actors and audience are truly engaged, a Forum Theatre exercise involves multiple playbacks and restarts from varying points throughout the scenario. It can become quite confusing for the Joker, the actors and the spect-actors who come onstage to keep track of where to begin each time someone volunteers to take the place of a cast member. This is especially true if time for repeated rehearsals is at a premium. Numbering the lines of the scripts make the multiple transitions and restarts much smoother. Using a line-byline script also ensures that the second run-through of the scenario will be the same as the first and hence that spect-actors can put into effect their reflection on the problems seen in the first iteration. Using a line-by-line script also helps when you use actors who are not totally familiar with the aims and objectives of the particular lesson and the theoretical debates underlying the embedded issues. Even expecting them to extemporize around detailed points is very demanding and risks the actors missing the nuances of the intended issues.

Finally, we recommend de-emphasizing the importance of the substantive law and the legal issue by communicating at the outset that the exact legal problem is not important. We found that when we demonstrated this methodology to other clinical educators, many wanted to solve the legal problem for the client, but were understandably without sufficient knowledge of the law on which the scenario is based. We adapted our rules afterwards to make clear from the beginning that the purpose of the exercise is to develop interviewing skills and ethical interaction of the law student clinician with the prospective client, that the particular legal question presented was not relevant, and that there was no need to solve the legal issue. 


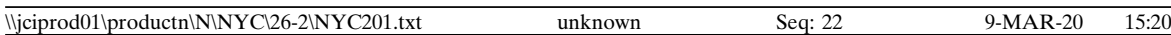

The problem of the substantive legal issue presents in a different way at the Universities of Essex and Strathclyde, where most students have had even fewer substantive law courses than those in the U.S., and are therefore very unlikely to know the law relevant to the scenario. This means that they might struggle to ask the right questions or to correct legal advice given in a manipulative or otherwise paternalistic way; not because they cannot correct the paternalism but because they may not be able to ask the right questions without knowing the law. For this reason, for training at the University of Essex, the original passage in the Porn Star scenario in which the advisor gives fairly detailed and highly technical advice has been replaced with one in which the advisor simply raises the client's expectations of a positive outcome. ${ }^{81}$

\section{Keep In Mind The Learning Outcomes}

Many of the foregoing suggestions are quite specific to the scripted scenarios that are provided. The Vulnerable Client scenario is a very "entry level" foray into using Forum Theatre to train incoming clinical students. The Porn Star scenario is more demanding of the students. The "Wrong Client" scenario is far more subtle - in fact, so much so that in some cases, even with more sophisticated students or practitioners, one can reach the end without all the ethical issues being spotted.

Although this may seem obvious, perhaps the most important point to bear in mind with these scenarios is that the Joker must not lose sight of the learning outcomes of Forum Theatre, as discussed above. When it comes to teaching ethics, as opposed to more technical skills, Forum Theatre may work better as more of an 'issue-spotter' exercise designed to bring home the importance of having enough ethical knowledge to identify moral issues (i.e., what James Rest and other moral psychologists call "moral sensitivity"). ${ }^{82}$ On the other hand, Forum Theatre may not be best utilized for development of the "moral judgment" necessary to resolve them, which is perhaps better suited to seminar discussion and actual clinical practice and reflection.

81 Lines 30-31 on the fourth page of Script 2 (starting "Wow. . . sure. . . well. . . You clearly have a potential claim . ..") have been replaced with "Advisor: Wow. . . sure. . . well. . . Sounds like you've got a claim for something don't you think?"

82 James Rest, The Major Components of Morality, in Morality, Moral Behaviour and Moral Development (William Kurtines \& Jacob Gewirtz eds., 1984); James Rest \& Darcia Narvaez, Moral Development in the Professions: Psychology and Applied Ethics (1994); Darcia Narvaez \& James Rest, The Four Components of Acting Morally, in Moral Development: An Introduction (William Kurtines \& Jacob Gewirtz eds., 1995); James Rest, Darcia Narvaez, Muriel J. Bebeau, \& Stephen J. Thoma, Post Conventional Moral Thinking: A Neo-Kohlbergian Approach (1999). 
\begin{tabular}{lllll}
\hline |ljciprod01 $\mid$ productn\N\NYCl26-2\NYC201.txt & unknown & Seq: 23 & 9-MAR-20 & 15:20 \\
\hline
\end{tabular}

Furthermore, the "moral motivation" to care about ethics and the "moral courage" to face down countervailing pressures to act in ways thought not to be ethical, are arguably better taught through live-client clinical experience. ${ }^{83}$

We have realized that it is easy to become caught up in the excitement of Forum Theatre and view it as a panacea for ethics training. This risks blurring the lines between the relevant learning outcomes. The authors therefore suggest that those using Forum Theatre should clearly explain the ethics-related learning outcomes to participants from the outset to avoid any uncertainty or conflation of its purpose. Otherwise, in the authors' experience, Forum Theatre can confuse participants and suppress dialogue amongst them whilst giving them the impression that they are in fact being didactically "taught" how to resolve the moral issues raised in the scenarios. Participants should be reminded that ethical practice is not a skill that can be taught entirely over the course of training sessions such as Forum Theatre, a course in ethics, nor even one's time working in a law clinic. Ethical judgment is improved over the course of a career, building upon one's moral sensitivity as a continuous process of reflection, theorizing and experimentation. Indeed, the solutions we suggested by the appended scripts are rarely so easy to implement in practice, particularly for those serving vulnerable client groups where resources are often scarce. We therefore stress the importance of providing a setting in which participants can develop these skills following Forum Theatre and experiment with client interviewing as part of a comprehensive ethics and clinical curriculum.

\section{CONCLUSION}

We suggest that Forum Theatre is extraordinarily useful in training law clinic students as well as helping practicing lawyers and judges learn skills and ethics; and that it is particularly useful in surfacing the many overtly and covertly oppressive and paternalistic acts, micro-aggressions and denials of autonomy that impoverished and vulnerable clients experience when they interact with lawyers and the law. ${ }^{84}$ As

83 See e.g. Aiken, supra note 52, at 47; Newman \& Nicolson, supra note 53, at 48-49; Nicolson, supra note 53, at 165; Webb, supra note 53, at 296; Andrew Boon, Ethics in Legal Education and Training: Four Reports, Three Jurisdictions and a Prospectus, 5 Legal ETHICs 34, 60 (2002); Deborah L. Rhode, Into the Valley of Ethics: Professional Responsibility and Educational Reform, 58 L. \& Contemp. Probs. 139, 141 (1995). But see the Giving Voice to Values programme developed at Australian National University and described by Holmes, supra note 47, at 113.

84 See Peggy C. Davis, Law As Microaggression, 98 Yale L.J. 1559 (1989); Peter Margulies, The Mother with Poor Judgment and Other Tales of the Unexpected: A Civic Republican View of Difference and Clinical Legal Education, 88 Nw. U. L. REv. 695 (1994); Paul 
Boal puts it, "Hamlet says in his famous speech to the actors that theatre is a mirror in which may be seen the true image of nature, of reality." 85 We urge clinical legal educators to consider adopting this training method, not only for incoming students, but also in order to hold up the mirror to those in practice so that all can see and transform this reality.

R. Tremblay, Rebellious Lawyering, Regnant Lawyering, and Street-Level Bureaucracy, 43 Hastings L.J. 947 (1992).

85 Boal, Legislative Theatre, supra note 73 , at 9. 
Appendix

\section{Script 1}

\section{"The Vulnerable Client"}

\section{Characters}

Joker

Law Student Interviewer

Client- Elisa (or Eduardo)

Client's friend and helper- Rachael (or Rafael)

\section{Setting}

Interview room with table/desk with three chairs. Two chairs are on one side of the table facing the other chair. The table is covered with lots of confidential files and papers with client names on the front. Some of the files are placed on the chair.

\section{Key}

Suggested issues are in italics.

\section{Stage directions in bold.}

Note

The issues with the interview that have been constructed are not exhaustive and may be identified together, or at different points of the scenario. Improvisation should be used by actors to accommodate variances in the script that are pointed out by participants and to show how the interview might be improved.

\section{How it works}

The Joker begins by explaining how the Forum Theatre will work and in particular that:

1. Forum Theatre is also called 'theatre of the oppressed' and that the focus will be on how the law student advisor's actions will affect the client who is oppressed or at least treated unethically in this situation.

2. The scenario is first acted out once with no interruptions.

3. The scenario is then acted out a second time, but that the Joker will now invite participants to shout "Stop" when they see something which they think the advisor is doing which is incorrect and then step into the scenario and act out what they think that the advisor (and only the advisor) should have done instead. More specifically, the Joker explains that: 
- Participants (i.e., spect-actors) can decide where in the scenario to go back to in order to make their changes;

- Participants can stop another participant if they disagree with the changes they have made;

- If more than one participant shouts "Stop" then the Joker can invite one of those participants to step in and, after this, if the other participant has a different suggestion, can go back and allow them to do so as well;

- The Joker will decide when to stop the participant in order to continue;

- The Joker, together with actors, decides where to resume the scenario and continue in order for more participants to stop the scenario and make changes.

4. The Joker explains that once participants have finished making their changes, s/he will ask them questions about why they made the changes they did. These can include:

- Explain what you think the advisor was doing wrong just there?

- Why did you make that change?

- Why is this wrong?

- How would this make the client feel?

- How does this affect the lawyer-client relationship?

- How would this effect the interview?

- Explain the change that you made?

- Why is this change better than before?

- How is the change better for the client?

5. The Joker explains that the actors and participants will continue until the end of the scenario and participants have made all the desired changes.

6. The Joker explains that the focus is on correct interviewing techniques, and unethical and non-oppressive behavior rather than on determining what the correct law is.

\section{Introduction to the Scenario}

The Joker provides important background information, namely that:

- Strathflorida Health Rights Clinic is a fictional clinic that deals with issues ranging from health care and social welfare to housing. Any law referred to is fictional.

- Elisa is a 67 year old who is hard of hearing and, as a nonnative English speaker, a little slow to understand English. She is on a low income and is working past retirement age as a housekeeper.

- Rachael is Elisa's neighbor who "helps" her. She speaks fluent 
English. She is friends with Elisa, and she has accompanied her to the initial meeting today.

- Elisa and Rachael have come to the clinic with an issue over Elisa's housing benefit. 


\section{Script}

1 Elisa and Rachael walk into the room. The law student has a

2 chaotic air about him/her and seems unprepared for the

3 meeting.

Law Student: [looks up briefly from his work] Um, just... take a seat. I'll be with you in a moment. Miss ... ?

38 Law Student: What is it, Diane? I'm in a meeting ... Yes, that's

39 right, we're in court on Wednesday ... Yes ... if you could get all

40 those files sorted by Monday, that would be great. .. I mean, we 


\begin{tabular}{lllll}
\hline ||jciprod01\productn|N|NYCl26-2\NYC201.txt & unknown & Seq: 29 & 9-MAR-20 & 15:20 \\
\hline
\end{tabular}

1 have a real client problem, the guy just isn't believable, so we

2 need lots of help. Okay ...

3 Bye Diane.

[Law Student turns back to Elisa and Rachael, and rolls eyes.]

Ugh... Good help is hard to find. So, let's get on with this-

\section{[Just stares expectantly at Elisa and Rachael.]}

- Issue: lack of professionalism-use of phone, distasteful jokes, disparagement of a client

- Breach of client confidentiality

Elisa: [in heavy Spanish accent] I - I can't pay for my house, $y$ yo work mucho, mucho, y pago, pay ...

\section{[Cut off by Law Student.]}

Law Student: So, Elisa, do you own or rent your home? [to Elisa]

- Issue: Rude and overly controlling of listening stage of interview

\section{[Elisa and Rachael speak briefly in Spanish.]}

Rachael: Elisa rents her home. I have seen her write monthly checks, so it must be for the rent.

Law Student: Okay, [taking notes from Rachael's statement] and how long have you lived in the house?

39 Law Student: Okay, and when did the housing benefit get cut

Elisa: [in broken English] tw ... elve años y ... [cut off by Rachael].

Rachael: Twelve years. Her housing benefit has been cut off. off? [shifts body language to address Rachael] 
1 Elisa: [starts trying to answer, but struggles to find words].

3 Law Student: [to Elisa] It's okay, you don't have to worry.

4 Rachael can answer for you in English.

\section{[Elisa looks dejected and detached from the interview.]}

- Issue: improper use of a translator/facilitator

- Issue: poor communication with translator and client

Rachael: The subsidy stopped in April. We called the department, but they kept giving us different numbers to call to fix it. We went around and around, but it never went anywhere. I know Elisa can't afford the housing bills on her own.

Law Student: Basically, we can either ask for a fair hearing, which takes about 90 days and if we're successful the subsidy would be reinstated and back-dated to April, or we can re-apply, which takes about 30 days and the subsidy would resume as soon as the application is processed. Which would you prefer?

[looking at Rachael]

- Issue: student providing legal advice without supervision

- Issue: lack of communication with the client

- Issue: legalese and assumption of knowledge on client's part

Rachael: Um ... I'm not sure. [looking at Elisa, who remains detached]

Law Student: Well, I think we should just re-apply to get this started again rather than wait for the department any longer than we have to. Can you explain that to Elisa?

\section{[Rachael speaks to Elisa, who seems confused but still dejected.]}

- Issue: decision-making power taken from the client

- Issue: waiver, compromise of client's potential recovery without informed consent 


\begin{tabular}{lllll}
\hline |ljciprod01 $\backslash$ productn\N\NYCl26-2\NYC201.txt & unknown & Seq: 31 & 9-MAR-20 & 15:20 \\
\hline
\end{tabular}

1 Law Student: Also, I need this retainer signed. We don't charge

2 for our work here at the clinic because we're students and we

3 don't get paid anyway. It's just to get the ball rolling. Here, get

4 her to sign it please.

\section{[Law Student hands paper and pen to Rachael.]}

- Issue: no explanation of the form to the client

9 - Issue: paternalistically telling client what to do

10 - Issue: patronizing and lack of professionalism

[Rachael tells Elisa to sign the form. Elisa is confused and doesn't want to sign. Rachael becomes forceful, and Elisa eventually gives up and signs the retainer.]

\section{Law Student: It was good to meet you [shakes Rachael's hand].} I need to get back to work now, but I'll be in touch. Just head out that way and hang a left down the hall. [looks down at his/her papers]

- Issue: student did not monitor or interfere in the client/friend interaction and hence can be said not to have been instructed by the client

- Issue: did not explain when and how the client would hear from the clinic

- Issue: continued improper communication with translator

[Elisa and Rachael leave. Elisa continues to appear withdrawn and confused.] 


\section{Script 2}

\section{"The One With the Porn Star Teacher"}

\section{Characters}

Joker

Client: Miss Wanda Seymore (or Mr Will Seymore)

Law Student Advisor

\section{Setting}

Interview room containing a desk/table with two chairs. The table is covered with lots of confidential files and papers with client names on the front. Some of the files are placed on the chair.

\section{Key}

Suggested issues in italics

Stage directions in bold

\section{Note}

The issues with the interview that have been constructed are not exhaustive and may be identified together, or at different points of the scenario. Improvisation should be used by actors to accommodate variances in the script that are pointed out by participants and to show how the interview might be improved.

\section{How it works}

The Joker begins by explaining how the Forum Theatre will work and in particular that:

1. The scenario is based on a real law clinic case, that Forum Theatre is also called 'theatre of the oppressed' and that the focus will be on how the law student advisor's actions will affect the client who is oppressed or at least treated unethically in this situation.

2. The scenario is first acted out once with no interruptions.

3. The scenario is then acted out a second time, but that the Joker will now invite participants to shout "Stop" when they see something which they think the advisor is doing which is incorrect and then step into the scenario and act out what they think that the advisor (and only the advisor) should have been done instead. More specifically, the Joker explains that:

- Participants (i.e., spect-actors) can decide where in the scenario to go back to in order to make their changes;

- Participants can stop another participant if they disagree with the changes they have made; 
\begin{tabular}{lllll}
\hline |ljciprod01\productn\N\NYCl26-2\NYC201.txt & unknown & Seq: 33 & 9-MAR-20 & 15:20 \\
\hline
\end{tabular}

- If more than one participant shouts "Stop" then the Joker can invite one of those participants to step in and, after this, if the other participant has a different suggestion, can go back and allow them to do so as well;

- The Joker will decide when to stop the participant in order to continue;

- The Joker, together with actors, decides where to resume the scenario and continue in order for more participants to stop the scenario and make changes.

4. The Joker explains that once participants have finished making their changes, s/he will ask them questions about why they made the changes they did. These can include:

- Explain what you think the advisor was doing wrong just there?

- Why did you make that change?

- Why is this wrong?

- How would this make the client feel?

- How does this affect the lawyer-client relationship?

- How would this effect the interview?

- Explain the change that you made?

- Why is this change better than before?

- How is the change better for the client?

5. The Joker explains that the actors and participants will continue until the end of the scenario and participants have made all the desired changes.

6. The Joker explains that the focus is on correct interviewing techniques, and unethical and non-oppressive behaviour rather than on determining what the correct law is.

\section{Introduction to the Scenario}

The Joker provides important background information, namely that:

- The University of Strathclyde Law Clinic (USLC) is a university law clinic located in the city of Glasgow, Scotland, which deals primarily with employment, housing and consumer issues. Any reference to law is under the jurisdiction of UK employment law or Scots law. Please note that any reference to UK employment tribunal procedure was correct at the time of the writing of this script, but may have been subject to change.

- Wanda/Will Seymore is a 36 year old. S/he had been working as a drama teacher at a local privately funded, Catholic faith high school. This scenario is based on a previous USLC client. However, client details have been anonymized in the interests of confidentiality. Creative license has also been used in devis- 
ing the exact legal issues and facts of the case.

- The advisor is a student volunteer of the USLC with limited experience of employment law aside from USLC intake training sessions and experience of previous law clinic cases. They are in the early years of their undergraduate degree and have not studied employment law in detail or as part of their degree curriculum.

- USLC procedures and practice rules apply in the scenario.

- Wanda/Will has come to the clinic for an initial interview regarding an employment issue. 


\begin{tabular}{lllll}
\hline |ljciprod01\productn\N\NYCl26-2\NYC201.txt & unknown & Seq: 35 & 9-MAR-20 & 15:20 \\
\hline
\end{tabular}

\section{SCRIPT}

1 [Client walks in cautiously as the advisor is working on some

2 cases. The advisor has a chaotic air about him/her and seems 3 unprepared for the meeting.]

39 [The advisor is still unable to find the client's file so interrupts

- Issue: chairs not laid out in a good way and should preferably be in the round

Advisor: [looks up briefly from their work] um, just eh...take a seat, I'll be with you in a moment Ms...?

Client: Seymore, Wanda Seymore

[Advisor waves his hands toward the chair on the opposite side of the table. Client approaches the chair, but it is covered in files.]

Advisor: oh, erm... let me move some of those... [Advisor goes to clear the chair] Can you just hold these for me a second? [passes case files to client to hold whilst he clears the chair]

- Issue: messy setting and hence unprofessional impression

- Issue: duty of confidentiality is breached if the client sees names on files

Advisor: So let's get on with this then.

[Advisor scrambles around for the client's file, not looking up at the client. Awkward silence follows as client is unsure whether to begin. Advisor eventually looks up at client giving her an expectant expression.]

- Issue: no formal introduction or run-through of clinic procedures in relation to the initial interview

- Issue: unwelcoming attitude which has a negative effect on the lawyer-client relationship

Client: okay... well I've been working.... the client to shout through to the clinic administrator.] 
1 Advisor: Just a moment [shouting through to another room]

2 Donald.... Have you got the file?...The file for the interview

3 with Ms Seymore..., Ms Wanda Seymore... Oh yes, that's right

4 we're in court on Wednesday for the Buchanan matter have you

5 got that file too?... okay... bye Donald.

- Issue: shouting client's name across rooms in a potentially busy clinic would breach confidentiality and may make the client feel uneasy

\section{[Advisor gets up to leave and collect file from the off stage} office. Returns holding the client's file.]

Advisor: Bloody student interns! So, you were saying?

- Issue: might offend client, alienate her or at least make her feel awkward

Client: So.... [Long pause as she finds her train of thought again] Okay, I've been working for Saint Diane's College, a catholic high school in Glasgow, for a good while - must be five years now on a permanent contract. I teach Drama.... I'm actually classically trained. I have a Bachelor of Arts Honours degree in Contemporary Performance Practise from the National Theatre School, and I really enjoy working with young adults, helping them to realise their potential and explore...

\section{[As client says this, the advisor interrupts the client by holding} up hand.]

\section{- Issue: interruption to client's flow}

Advisor: [with a patronising tone] Soooo.... if you could...you know... just keep to what's actually relevant [laughing awkwardly] that would be great.

Client: [sheepishly] Oh I'm sorry.

Advisor: [again, with a patronising tone] Really don't worry about it. You are not legally trained. 


\begin{tabular}{lllll}
\hline I|jciprod01\productn|N|NYCl26-2\NYC201.txt & unknown & Seq: 37 & 9-MAR-20 & 15:20 \\
\hline
\end{tabular}

- Issue: confusing client - they would be unsure as to what is important or not, so making them feel uneasy.

- Issue: advisor assumes s/he knows what is relevant

- Issue: failure to build strong client-lawyer relationship

Client: Okay, well I was working there for about five years as I said and all of a sudden last month I was told that I was being dismissed. I went in one day as if everything was normal. [At this point, the advisor slyly checks their mobile phone from their pocket.] I walked into my classroom and there was a substitute preparing her lessons and all my belongings were sitting in a box on my desk. Next thing I know the head comes through with a letter saying that I had been sacked, and I was given my final payslip. She said to me, "I'm sorry, but there's nothing I can do. You'll be paid until the end of the term." Just like that. It was so out of the blue I just don't understand. I've been nothing but reliable and an asset to that place. That was a sorry excuse of a department before I was there. And the only reason I can maybe think of is that...

- Issue: not giving client full attention and hence not listening properly

Advisor [interrupting]: Okay, okay. So here's how it is. Ms Seymore? [looks to client] You've been working there for four years.

Client: Five years.

Advisor: Oh, sorry five years and what kind of a contract were you on?

Client: A permanent contract, as I said before.

- Issue: not listening to client

Advisor: Oh... So, do you know what reason they gave for

38 dismissing you? 


\begin{tabular}{lllll}
\hline |ljciprod01 $\backslash$ productn\N\NYCl26-2\NYC201.txt & unknown & Seq: 38 & 9-MAR-20 & 15:20 \\
\hline
\end{tabular}

1 Client: [beating around the bush] Well I'm not entirely sure, I

2 think they decided that I wasn't quite... appropriate to be facing

3 the students anymore...

Advisor: Look, in order to work on your case, we need to know everything, I mean, it's not like you're sleeping with the school kids!? [laughing awkwardly] [pause] You aren't are you?

- Issue: careless questioning and potentially very condemnatory of client if she was in fact sleeping with pupils

Client: No, no, no, no! Well... in a previous life I may have been involved in some adult films....to pay my way through university... [Advisor's eyes widen. Client is put off by the advisor's expression but continues.] So apparently, one of my students may have... somehow... managed to get a hold of one...

Advisor: No judgment here, but gosh... a Catholic teacher in porn... I mean you really couldn't make it up...

- Issue: judgmental towards client

Client: ...Adult film industry. And it was something I did in the past before I had even considered being a teacher and I would really like to move on from actually... Besides I'm not sure how they think that this even affected my teaching.

Advisor: Wow... sure... well... You clearly have a potential claim for unfair dismissal and we need to get moving and submit our claim to the employment tribunal and complete the ET1 form. Before we can even think about that we need to go ahead with the mandatory ACAS early conciliation. Just to warn you, employment law is very fast paced, and we need to move quickly and to submit your claim within three months minus a day from when you were dismissed. So are you clear on that?

- Issue: giving advice which has not been checked by a supervisor, contrary to USLC rules

- Issue: using legalese 


\begin{tabular}{lllll}
\hline |ljciprod01 $\backslash$ productn\N\NYCl26-2\NYC201.txt & unknown & Seq: 39 & 9-MAR-20 & 15:20 \\
\hline
\end{tabular}

1 Client: Sorry, what is an ET1? What is ACAS?

2

Advisor: Just lawyer stuff, pet. Let us professionals deal with that.

- Issue: patronizing

- Issue: paternalistically depriving client of their autonomy

Client: Wow, employment tribunal... that's pretty daunting [looking unsure]. I mean I read somewhere that you do, I think it's called meditation or is it mediation? I mean do you think it would be any help just trying to sit down with them and getting the chance to explain myself?

Advisor: I'm not going to lie to you pet, mediation is more like a sort of soft law. A complete waste of time. So, I'll go ahead and start working on your ET1 then shall I?

- Issue: patronizing

- Issue: invading client autonomy by unilaterally deciding on course of action

Client: Um... sure?

Advisor: Perfect. You know something; I have a really good feeling about this one. This is very clearly an unfair dismissal. I think the judge will $100 \%$ be on your side and you would come across as a very credible witness. So, I would be more than happy to represent you.

- Issue: not managing client's expectations but giving her possibly false hopes

Client: Oh wow... great... thank you! I mean it doesn't even seem as if I told you half of it.

Advisor: I mean, if we can settle, then perfect. From my experience, the Council will very often pay up big time the moment they see our headed letter and the ET 1 form. And I mean big, some of the settlements we've had from the Council have been pretty big... Well, maybe not for porn stars... 
- Issue: not listening to her

- Issue: not managing client's expectations but giving her possibly false hopes

- Issue: judgmental

Client: [correcting advisor] ...Adult film star. That would be good I suppose, but I'm more just so embarrassed and insulted that they think this could affect my teaching, I mean I just love my job and can't imagine doing anything else.

Advisor: [dismissive] Yes, yes of course, but don't worry, we'll push for a pretty hefty settlement. So now for the boring paperwork. So here is a copy of our data protection policy, a mandate for us to act on your behalf, and some other forms if you could just have read through of those and give them a signature that would be great. After that, the door is over there and you can find your own way out can't you?

\section{[Advisor throws the forms across the desk and goes back to work]}

- Issue: continuing to assume what client actually wants (i.e.,compensation rather than her job back)

- Issue: assuming that the client properly understands the forms and hence not explaining them

Client: um ... so... what is this about confidentiality, are you going to pass on my details to anyone?

Advisor: Don't you worry about that pet, just give it a signature at the bottom there.

- Issue: patronizing and paternalistic

Client: Thank you for your time. Sorry, what was your name again?

Advisor: [not listening to client, but noticing she is still in the room] Oh, have your forgotten the way out? Just out there and to the left. 


\begin{tabular}{lllll}
\hline I|jciprod01|productn|N|NYC126-2INYC201.txt & unknown & Seq: 41 & 9-MAR-20 & 15:20 \\
\hline
\end{tabular}

Spring 2020] Theatre and Revolution in Clinical Legal Education

1 - Issue: still not introducing self to the client

2 - Issue: not escorting client out

3

4 Client: Should I call you, or will you get back to me?

5

6 Advisor: [not looking up from their work] Don't worry, I'll be in 7 touch.

8

13

12 Client: okay.. bye...

- Issue: not explaining when and how the client will hear from the advisor

\section{[Advisor still doesn't look up. Client exits]}

- Issue: very rude and leaving client with a very bad impression 


\section{Script 3}

\section{"The Wrong Client"}

\section{Characters}

Joker

Client

Law student advisor

\section{Setting}

Interview room containing table/desk with two chairs

\section{Key}

Suggested issues in italics

\section{Stage directions and instructions to Joker in bold}

\section{Note}

The issues with the interview that have been constructed are not exhaustive and may be identified together, or at different points of the scenario. Improvisation should be used by actors to accommodate variances in the script that are pointed out by participants and to show how the interview might be improved.

\section{How it works}

The Joker begins by explaining how the Forum Theatre will work, and in particular that.

1. The scenario is based on a real law clinic case, Forum Theatre is also called 'theatre of the oppressed' and that the focus will be on how the law student advisor's actions will affect the client who is oppressed or at least treated unethically in this situation.

2. The scenario is first acted out once with no interruptions.

3. The scenario is then acted out a second time, but that the Joker will now invite participants to shout "Stop" when they see something which they think the advisor is doing which is incorrect and then step into the scenario and act out what they think that the advisor (and only the advisor) should have been done instead. More specifically, the Joker explains that:

- Participants (i.e., spect-actors) can decide where in the scenario to go back to in order to make their changes;

- Participants can stop another participant if they disagree with the changes they have made;

- If more than one participant shouts "Stop" then the Joker can invite one of those participants to step in and, after this, if the 


\begin{tabular}{lllll}
\hline |ljciprod01\productn\N\NYCl26-2\NYC201.txt & unknown & Seq: 43 & 9-MAR-20 & $15: 20$ \\
\hline
\end{tabular}

other participant has a different suggestion, can go back and allow them to do so as well;

- The Joker will decide when to stop the participant in order continue;

- The Joker, together with actors, decides where to resume the scenario and continue in order for more participants to stop the scenario and make changes.

4. The Joker explains that once participants have finished making their changes, s/he will ask them questions about why they made the changes they did. These can include:

- Explain what you think the advisor was doing wrong just there?

- Why did you make that change?

- Why is this wrong?

- How would this make the client feel?

- How does this affect the lawyer-client relationship?

- How would this effect the interview?

- Explain the change that you made?

- Why is this change better than before?

- How is the change better for the client?

5. The Joker explains that the actors and participants will continue until the end of the scenario and participants have made all the desired changes.

6. The Joker explains that the focus is on correct interviewing techniques, and unethical and non-oppressive behaviour rather than on determining what the correct law is.

\section{Introduction to the Scenario}

The Joker provides important background information, namely that:

- The University of Strathclye Law Clinic (USLC) is a university law clinic located in the city of Glasgow, Scotland, which deals primarily with employment, housing and consumer issues. The applicable law is that of Scots law and the ethical rules are that of Law Society of Scotland;

- The client, Danny Ashurst, is in his mid-twenties and is welleducated, having a university degree, as well as years of experience working as a volunteer in homeless shelters;

- He has booked in an appointment to see if he can get out of a contract he has entered into on behalf of his employer. 


\section{SCRIPT}

\section{Law Student introduces her/himself, goes through relevant clinic} formalities and asks how s/he can help.

28 Issue: slightly patronizing but definitely running the risk of giving

$$
\text { Danny: I'm here on behalf of my employer, Glasgow Housing. }
$$

\section{Law Student: Okay.}

Danny: You see I've got myself into big trouble by entering a contract that the business actually wants to get out of. I'm worried about losing my job.

\section{Law Student: I see.}

Danny: And it's a dream job because I have always worked with the homeless and things were going so well. Now I can't sleep at night.

\section{Issue: there is immediately a potential conflict of interest - see} below

\section{[As this issue is rarely spotted at this stage, it can be left until the end or whenever it arises.]}

Law Student: Okay, deep breath. Don't worry. I am sure we can sort this. Just take your time and tell me everything from the beginning. client false hope

Danny: I am the office manager of Glasgow Housing which helps homeless persons. The company is run by a board of directors, who gave me a list of office furniture to buy. I was asked to get quotes for the items and then get their authorization. So about two weeks ago - I think it was the $12^{\text {th }}$ - I visited Hutchisons Business Supplies and spoke to their salesperson, Jacky....I cannot remember her surname.

Law Student: Don't worry now. We can always get the details 41 now. 


\begin{tabular}{lllll}
\hline |ljciprod01 $\backslash$ productn\N\NYCl26-2\NYC201.txt & unknown & Seq: 45 & 9-MAR-20 & 15:20 \\
\hline
\end{tabular}

1 Danny: Ok. So, I told Jacky that I was the manager of Glasgow

2 Housing and gave her my list. She agreed to give me a quote

3 with a breakdown of the cost of each individual item in a couple

4 of days time.

6 Law Student: Sorry to interrupt, but did you tell Jacky that you

7 required authorization from the board?

9 Danny: No, I was confident that I would get authorization to buy the items on the list, provided that the price was right.

Law Student: Okay, sorry to interrupt, what happened next?

Danny: Two days later, Jacky phoned me and offered me a "job lot" of items for £6250, which meant we got more things than we needed. I thought it was a great deal as we could sell the extra things we didn't need. So I just accepted it and she agreed to deliver the items on the $18^{\text {th }}$.

\section{Law Student: I see. Go on.}

Danny: I mean I probably should have checked with the chief executive, but she was on holiday until the $20^{\text {th }}$ and anyway I thought that there would be no problem.

\section{Law Student: Was there?}

Danny: Well, when I did tell the board, they asked if I'd seen any of the furniture. I said that I had not seen every item as all the furniture in the store was of good quality. But the board was unhappy and told me to cancel the order until I had seen the goods. I went off to phone Jacky, but unfortunately, there was a bit of delay. You see.... [long silence]. Well... [long silence]. You see... well let's just say there was a delay as I got distracted.

Law Student: Okay, it might not be important, but I am afraid I don't know that until you tell me why there was delay. So, if you don't mind, can you do so. Otherwise it's going to be difficult for me to give you the best possible advice, Remember, everything

41 forced to divulge it. 
1 Issue: not strictly true - a court could require disclosure which

2 can only be resisted on legal professional privilege if the advice is

3 being given in contemplation of litigation.

Danny: Well, okay, if this is confidential...before I had time to cancel the order I bumped into one of the volunteers who was very upset because she had come to suspect that one of the

8 Board members was using his position to "groom" some of our 9 younger homeless clients.

$40 \quad[(a)$ and (b) involve the lawyer moralistically impinging on

41 client's autonomy so can be used to explore issue of client 
1 autonomy. Actor playing law students can choose (a) or (b) to

2 ascertain response from audience, for instance, as follows:]

3 (a) Law Student: Well if you won't do the right thing, I am not going to act for you.

Issue - abuse of client's need for legal help (possibly his or her last resort if they are going to a law clinic) in order to effectively blackmail him/her to ensure that student's moral values take precedence over values or at least practical interests of client.

(b) Law Student: What? You really think you are more important than these poor children? You are happy to put your career before them? How can you?

Danny: No but....and

Issue: abuse of position of person in perceived authority and hence invasion of client's autonomy to make own decisions

[After the options are explored, the Joker can explain that the lawyer could offer to go to police for Danny and that, if the Law Student is authorized to give on the spot advice they could outline to the client that Danny might be liable for not going to police if $\mathrm{s} / \mathrm{he}$ is in a position of trust of a vulnerable person. But if s/he does, they might be protected against dismissal as a "whistle-blower" which means that they can try to stop their dismissal through the courts or, if they are dismissed, they can claim compensation. If the Law Clinic does not allow on the spot advice, this could be explained by the Joker. Subsequently, the actors should return to the main script by wrapping up the sexual abuse issue as follows:]

Law Student: Look it's your decision as to whether you report or not and I don't want to force you to do something you have good reason not to want to do. However, I am not sure about the details, but it might be possible for me to do so on your behalf if you would like me to. But as I explained to you earlier, I am not allowed to give you final advice without checking it with my supervisor. So, if you decide to do this route I can 
1 research and provide you with a much clearer idea of your legal

2 position in this regard.

3

\section{Danny: Ok, I will think about it.}

Law Student: Good, but perhaps don't leave it too long. There are people at risk. But let's get back to what happened next.

Danny: So, I spent most of the rest of day and well into the evening discussing the issue with the volunteer and completely forgot to phone Hutchisons to cancel the order. I did email first thing the next day (at $7 \mathrm{am}$ ), but it seemed to be too late as the Hutchisons driver turned up at 8 am before I arrived at work and delivered the goods. Am I going to lose my job?

Law Student: Well as I said we cannot advise you on the spot, but I can certainly research your legal position if you would like me to and get back to if you want me to.

Danny: Very much so.

Law Student: Okay, is there anything else I should know?

Danny: Oh yes, I almost forgot Hutchisons are now seeking payment for the furniture and I have been told to find out from you if we can avoid paying the money.

Law Student: Would you like me to research that as well?

Danny: Yes please.

Law Student: Okay let me get back to you a statement of the facts in the next few days and then when you return them to me I can start my research.

Issue: Both fiduciary law and ethical rules preclude lawyers (and University of Strathclyde Law Clinic law students) acting in matters where there is a conflict of interest between two clients. Danny approached the clinic as an agent for Glasgow Housing in relation to the contractual issues, but also asked for advice on his/her employment situation. Currently, there is no actual 


\begin{tabular}{lllll}
\hline ||jciprod01\productn|N|NYCl26-2\NYC201.txt & unknown & Seq: 49 & 9-MAR-20 & 15:20 \\
\hline
\end{tabular}

1 conflict of interests. However, there is a significant risk that one

2 will arise if the client is disciplined or dismissed, given that there is

3 likely to be a divergence between Danny's interests as an

4 employee of Glasgow Housing and that of the company itself,

5 and the clinic is likely to gain confidential information from each

6 relevant to the other. The clinic will then have to cease acting for

7 both. In cases of potential conflicts, the Law Society of Scotland's

8 code requires solicitors to be cautious and to only act for both

9 sides with both parties' full knowledge and express consent. Here,

10 Danny is highly unlikely to consent because s/he has provided

11 information relevant to a potential employment dispute.

12 Moreover, because the clinic has relevant confidential

13 information about Danny, it cannot act for Glasgow Housing as

14 s/he would either have to withhold information in their interests

15 or breach the duty of confidentiality owed to Danny. However,

16 unless Glasgow Housing is a pre-existing client of the clinic, it can

17 take on Danny and act for him against the company.

18 Danny: Sounds good, but I need to rush as I have to report back

19 to board.

20

21 Law Student: Okay, I will write to you as soon as possible on the 22 email address you have given me.

23 [Law student ends interview and says goodbye to Danny] 
